\title{
プッシュ式シンクロカッターの最新の実績と将来の展開について 一従来の概念を覆すカッター一
}

旭マシナリー株式会社 江 里 口誠

\section{The Latest Accomplishments and Developments in the Future of Push Type Synchronized Cutter -Innovation of Sheet Cutting-}

\section{Makoto Eriguchi}

Paper Making Machine Dept., ASAHI MACHINERY LIMITED

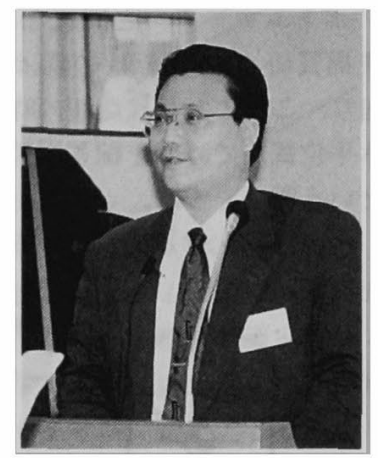

We take great pleasure in getting opportunity to speak in public in such an important seminar.

Since the Sasaki prize was awarded to us in 1995, PUSH TYPE SYNCHRO CUTTER is the object of attention, and we received many inquiries about it, which produced the good results of today.

An outline of the lecture is as follows:

(1) System and Structure of PUSH TYPE SYNCHIRO CUTTER (Contents omitted due to the limited space)

(2)Latest Accomplishment (Delivery results, technical evolution of the rotor and the cutter, etc.)

(3)Future Prospects (Further developing cutter, proposal of the new equipment, and our future prospects of the cutter)

PUSH TYPE SYNCHRO CUTTER is the latest cutter we have ever seen, and we have various kinds of assignments accordingly, which is worth while to do it for us as the technician.

We are grateful to the people who take an interest in our cutter and go on with negotiations constructively.

\section{1.はじめに}

近年, カッターパートの重要性は年々高まってきて いる。特に製品の品質面に於いて問題として上げられ るのは, 大きく分けて“切断面の紙粉の有無”, それ
に“寸法長短精度”である。

これらを解決するために考え出したのが, 旭マシナ リーの“プッシュ式シンクロカッター”で, このカッ ターは今までの概念を全く覆したカッタ一装置として， 平成 7 年度には, 佐々木貝まで頂き,引続き多くの注 
目を頂いている。

\section{2. プッシュ式シンクロカッターの説明}

\section{1 構 造}

プッシュ式シンクロカッターについて構造を図1に 示す。簡単に説明すると次の様になる。

下部フラットのホトトムローターと上部刃物ローター により構成され，この下部ローターはフィードロール と同速で一定回転を行い，上部ローターのみサーホトト ライブで加減速を行う。そして機戌的には, 刃物ロー ターと下部ローターのつながりはない。

上部刃物ローターは，シートを切断中のみ(ワーク アングル中）ホトムローターと同速となる（図2）。 そして, 刃先周長切 (Bo 運転) の時は加減速無しの 一定回転で回り，これより長尺切断の時は，刃先待機 位置 (刃物水平位置) で時間を稼ぎ短尺切断時は, 逆 に加速するという動きをする。

例之ば，刃先円径が $\phi 250$ とする。 $\phi 250 \times \pi=$

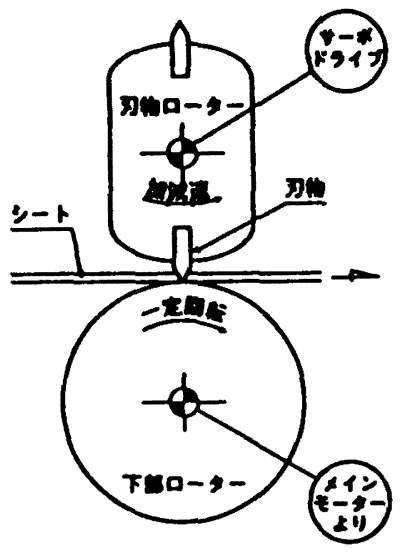

図 1 プッシュ式シンクロフライカッターの構造

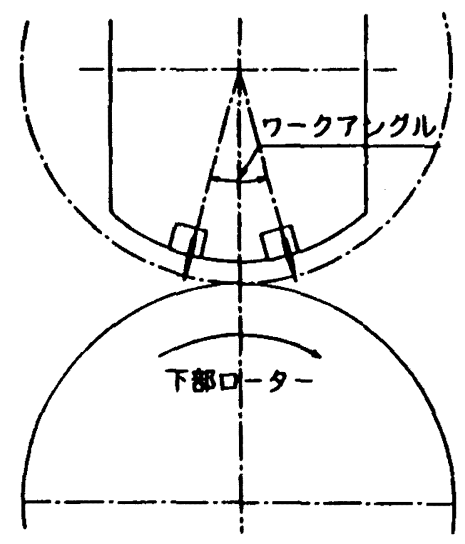

図 2 上部刃物ローターのワークアンクル
$785.40 \mathrm{~mm}$ が刃先円長（Bo）となる。よって，サー ボモーターは刃物ローターのみドライブするため，低 動力で済み, 又通常プッシュ式シンクロカッターは, 刃物ローターに2 枚の刃を入れることから更にBo か 短くなり，短尺切りが低動力で行えるというメリット も出てくる訳である。

そしてこれらサーボモーターに測長指令を与えるの がメシャーリンク装置であるが,これはシート上に值 接置くタイプとフィードロールに取り付けるタイプ, それに非接触により計測するタイプとカッターのオ ン・オフや用途，それに使い勝手等に合わせて使い分 けている。

\section{2 システム园}

図3にシステム困を示す。

\section{3 プッシュ式シンクロフライカッターの特徽}

次にプッシュ式シンクロカッターの特徵であるが, 刃物ローターと下部ローターは, 軸受ケースで連結さ れており，運転中でも刃物の押込量を $1 \mu \mathrm{m}$ 単位で調 整が可能である。そして，刃物ローターに取り付ける 刃物は市販の使い捨て品を使用しておりホールディン クはマクネットのみで行っているため，刃替えは抜き 差しのみで可能で, $2 \mathrm{~m}$ クラスのローターでも刃替時 間は数秒で行うことができる(図 4)。

以上は，これまでに無いカッター方式として既に特 許を取得斉みで，追加特許の件数も数十件に及び，現 在も随時出している。

\section{3. 最新の実嚗について}

\section{1 プッシュ式シンクロカッターの実紸}

当初はプッシュ式シンクロカッターの実績として, 上質紙及びアート・コート紙が主流であった。コート 紙においては，上質板紙共印刷時の紙粉クレーム及び 長短クレームの減少を目的に採用して頂いた。

しかし，最近はテスト機の見直し及び改善と新ロー ターの開発により，技術的に多くの問題点をクリアす ることが出来, 現在では高級白板紙の多層切りから $6.5 \mathrm{~mm}$ 厚の貼合原紙まで，それに 10 数クラムの薄 葉紙の多層切りからフィルムの多層切りまで, 巾広く 使うことができるようになった。

\section{2 技術的な内容について}

具体的には, 刃物ホルターの形状及び材質の見直し， そして精度 UP，それにローター及び軸受部の剛性 UP や精度 UPを行い, 開発当初よりも優れたカッ夕 一となった訳である。

刃先についても同様で, 開発当初は市販の刃物（ト ムソン刃）の使用を考えていたか，開発が進むにつれ 


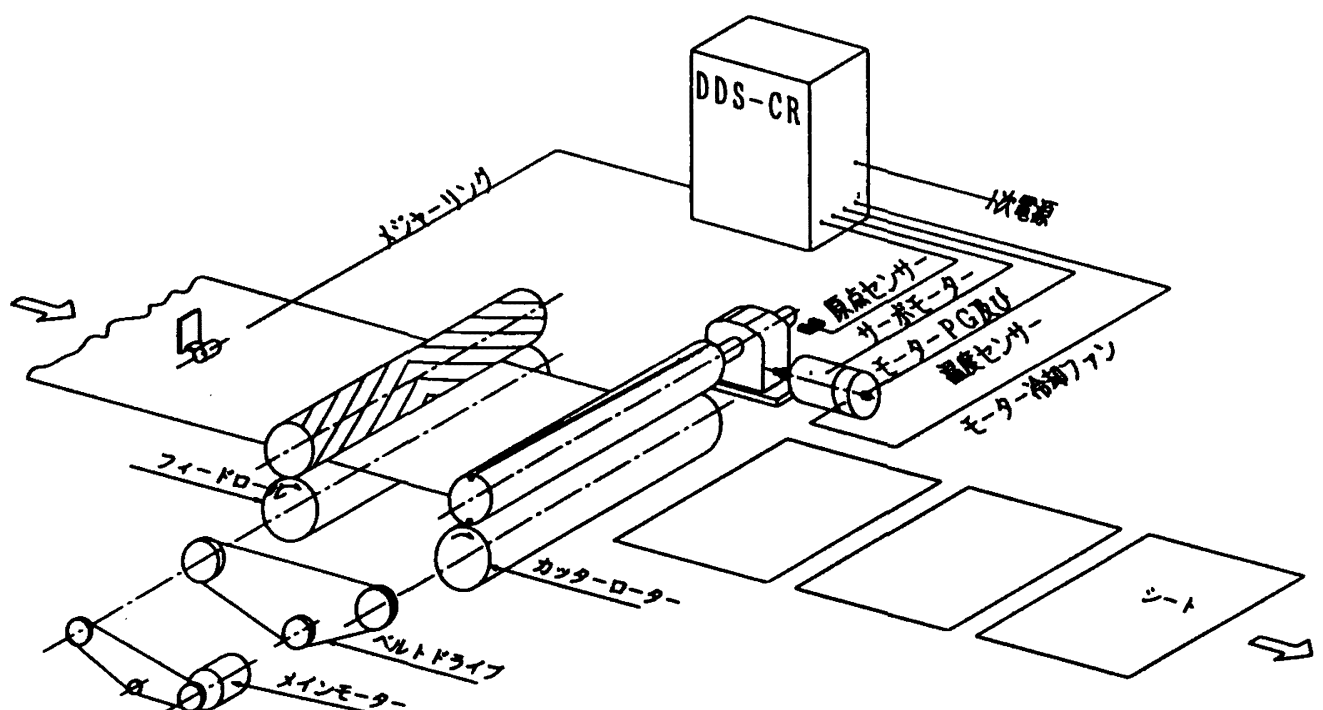

図 3 プッシュ式シンクロフライカッターのシステム

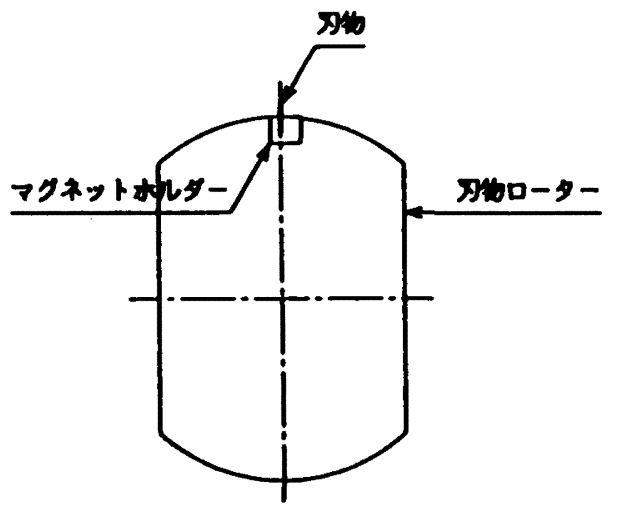

図 4 刃物ローターのマクネットホルター
板紙用，上質用，フィルム用等それぞれ専用の刃物が 必要なことが分かり，刃物メ一カーとタイアップして 数々の刃物を製作した。但し，これらは専用とはいえ， 使用方法はあくまで使い捨て品となる。 参考に刃先形状を図 5 にあげて示す。

上記刃物は, プッシュ式シンクロカッター用として 開発した物のほんの一例で，他にも数多くの刃物を製 作し, 実用化している。

3.3 プッシュ式シンクロカッターのスピードについて スピードに対する問題としてテスト機によるもので $300 \mathrm{~m} / \mathrm{min}$ は, クリアしているが, 実滞での要求は あまりなかった。というのも, 3.1 項で述べている様に, プッシュ式シンクロカッターは $2,000 \mathrm{~g} / \mathrm{m}^{2}$ までの断 裁が可能なため，スピードUPよりも多層切りによ

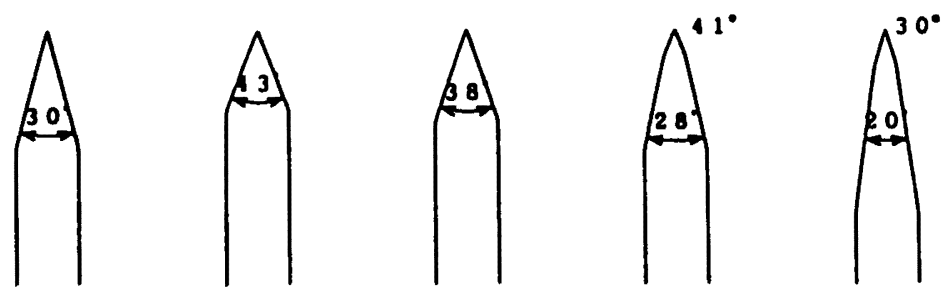

\begin{tabular}{|c|c|c|c|c|c|}
\hline 刃先沼状 & 128 & $12 x$ & 128 & 2 政为 & 2 政刃 \\
\hline 用文 & 企 & フィルム・上页 & フィルム・上界 & 上 $x$ & 板 \\
\hline${ }_{(\mathrm{mm})}$ & $0.5 \sim 0.9$ & $0.7 \sim 0.9$ & 0.9 & 0.9 & 0.9 \\
\hline
\end{tabular}

图 5 各種刃先形状例 
るメリットを要求されてきたからである。すなわち, コンべア速度を半分近くに下げられることから, 高い 安全操業が可能になるからである。

\section{4. プッシュ式シンクロカッターの将来的な展望}

現在開発中のものに次の様な物がある。

プッシュ式シンクロカッターは現在刃物の押し込み 量のコントロールを手動操作, 又は自動操作（オプシ ヨン) で行っている。この自動操作はカット枚数をカ ウントして自動下降していくタイプのものであるが, 最近では明産株式会社殿との共同開発により, 接圧セ ンサー等を用いたコントロールユニットを開発した。 これは刃物の押し込み量をカット枚数や下降パターン で決めるものではなく，電気的に検出して押し込み量 を決めるもので、将来はこのタイプが主流になるもの と思われる。

次に開発中のものが自動刃替装置である。御存知の ようにプッシュ式シンクロカッターは刃替が簡単であ る。よって、これを機械にさせることにより刃替作業 を押しホタン1つで行い, 人手による刃替作業を無く すのが目的である。

以上のようにカッターソーンは熟練者が必要不可欠 であったか, 旭マシナリーは熟練者の要らない, 又は
容易に誰にでも操業出来るカッターを供給することを 目標としている。

そして旭マシナリーには現在, 加工機事業部と抄紙 機事業部の両部門があり, プッシュ式シンクロカッタ 一は抄紙機械事業部が取り扱っている。

加工機事業部ではカートンマスターにクルアマスタ 一, それに印刷機等を取り扱っており, シートの搬送 技術はかなり高いものと自負している。

よって，これらの技術を融合させることにより，近 い将来カッターゾーンだけではなく, 前後装置につい てもハイレヘルな製品を供給出来るものと確信してい る。

\section{5.おわりに}

カッターパートにおいてはセミシンクロからフルシ ンクロ，そしてプッシュ式シンクロカッターの出現と 目まぐるしい近年であるが, 私共も現在の技術に胡座 をかくのでは無く，新技術の開発をどしどし行ってい く意気込みである。

最後に開発に当たっては, 我事のように御教示の上, 更にテスト原紙まで工面して頂いた各々の製紙会社の 方々には感謝の意が酎えません。この紙面を借りて厚 く御礼申し上げます。 


\section{巻取ロール包装の現状}

\section{川之江造機株式会社 近藤 真生}

巻取ロール (製品) を仕上げるワインターの自動化が進むにつれ，大量の製品が次工程に送られるよ うになってきた。それに伴い，包装関連装置の自動化，高速化が急速に要求される今日である。

従来の包装設備では人手の介在を必要としていた操作も，自動化された製品データのコンピュー夕管 理が進み，そのデータを包装関連装置へ通信することにより，各々の装置をオンラインで自動制御でき るようになってきている。また，抄䉻機 1 台に巻取包装機 1 台の組み合わせが通常であったものが, 複 数の抄紙機に対し 1 台の包装機で対応するといった構成が增えて来ている。

当社の巻取包装機は巻取ロール（製品）の包装を自動で行う装置であり，製品寸法の変化に対応させ るべくメカトロニクスの集合体として設計されている。巻取包装機は, バーコード読取装置, 印字機, 包装機, 胴マーキング装置, ラベル貼付機等の自動装置で構成され, 巻取りロールは完全包装された最 終製品として送り出される。

各装置に必要な運転データは, タッチパネルによって簡単に入力, 变更または監視が出来, これらデ ジタル化された制御によって，熟練した運転者でなくても比較的短期間に巻取包装機を運転できるよう になってきたのが現状である。

(本文 28 ページ)

\section{プッシュ式シンクロカッターの最新の実績と将来の展開について}

旭マシナリー株式会社 江里口 誠

プッシュ式シンクロカッターは，平成 7 年度の佐々木賞を受賞して以来，多くの注目を浴び，また， 多くの引き合いを頂いたことで今回のセミナ一発表に繫がったものと思っている。セミナーの発表につ いて，搔摘まんで説明すると，

(1)ブッシュ式シンクロカッターの構造, 及びシステム

(2)最新の実績

(3)将来の展望

と, 大きく 3 つに分けて話をさせて頂いた。

最新の実績については，現時点での納入実績からローターや刃物の技術的な内容等を述へる。また将 来の展望については, 現在開発中のカッター及び商品化前の附属装置の話, そして九旭マシナリーがカッ ター装置に対して将来展開していこうとしている内容を説明する。

プッシュ式シンクロカッターは，今までに無い全く新しいカッターなので，技術的に努力することも 多々あり，我々も技術者の端くれとして励みになっている。積極的に話を進めて頂いている関係者の 方々に对し深く感謝の意を表します。

(本文 35 ページ) 